\title{
Značenje funkcionalnosti vodopropusnih objekata u protuerozijskoj zaštiti na šumskim cestama
}

\author{
Muhamed Bajrić, Elma Ljevo, Dževada Sokolović, Adnan Hodžić
}

\begin{abstract}
Nacrtak - Abstract
Bosna i Hercegovina ima pretežno brdsko-planinsku konfiguraciju terena, bogata je razvijenom hidrografskom mrežom. Pri projektiranju i izgradnji mreža šumskih cesta učestala je pojava presijecanja stalnih ili povremenih vodotoka pa je zato prijeko potrebno planirati i graditi vodopropusne objekte.

Najrizičnija su mjesta, kada je u pitanju negativan utjecaj vodotoka na erozijske procese, upravo točke presijecanja šumske ceste rijekama i brdsko-planinskim vodotocima. Da bi se smanjio postotak neupotrebljivosti primarne mreže šumske transportne infrastrukture, treba pristupiti kvalitetnim rješenjima odvodnje površinskih voda i izgradnji prelazaka preko postojećih planinskih vodotoka. Vodna je erozija jedna od mogućih pojava, koja može nastati na kolničkoj konstrukciji, ako na odgovarajući način nije riješeno pitanje odvodnje površinskih i oborinskih voda.

Procjena erozijskih procesa prilikom provođenja istraživanja utjecaja hidrografske mreže na primarnu mrežu šumske transportne infrastrukture obavlja se na osnovi terenskoga snimanja stanja vodopropusnih objekata i kolničke konstrukcije u njezinoj neposrednoj blizini.

Prilikom istraživanja nisu analizirani tehnički elementi šumskih cesta (osim erodiranosti kolnicke konstrukcije), aktivnosti su usmjerene na vodopropusne objekte, odnosno njihovo stanje i eventualni utjecaj na erodiranje kolničke konstrukcije. Istraživanja su provedena u GJ »Neretvica« u okviru ŠPP »Konjičko«.

Analizirano je ukupno 129 različitih vodopropusnih objekata, od kojih su 16 mostova, 73 cijevna betonska propusta i 40 drugih tipova objekata. U okviru provedene analize vodopropusnih objekata obrađena je oštećenost i funkcionalnost vodopropusnih objekata te erodiranost kolničke konstrukcije u njezinoj neposrednoj blizini.
\end{abstract}

Ključne riječi: šumske ceste, vodopropusni objekti, kolnička konstrukcija, vodna erozija

\section{Uvod - Introduction}

Prilikom projektiranja šumskih cesta neizbježne su situacije na terenu koje zahtijevaju planiranje i građenje vodopropusnih objekata. Čak i kad su dobro locirani i pažljivo projektirani, negativni utjecaji na kvalitetu vode mogu nastati zbog šumskih cesta, ako se njima ne upravlja i ako se ne održavaju pravilno (Orndorff 2017). Neodgovarajuća je odvodnja jedan od glavnih uzročnika erodiranja šumskih cesta (Ice i dr. 2004). Vodopropusni objekti na šumskim cestama postavljaju se na mjestima gdje je potrebno propuštanje vode kroz trup ceste. Ta su mjesta pri- jelasci preko potoka, rijeka i sl., kao i mjesta gdje je zbog terenskih uvjeta i promjene oblika poprečnoga presjeka ceste potrebno odvođenje vode ispod trupa ceste (Sokolović i Bajrić 2013a). Najveću primjenu na šumskim cestama imaju cijevni betonski propusti (Sokolović 2018). Zbog prijelaska trase prometnice preko stalnoga ili povremenoga vodotoka potrebno je osigurati nesmetano strujanje vode. U nekim slučajevima neizbježno je izgraditi cestu preko postojećega potočnoga kanala. Na tim prijelazima potoka grade se mostovi ili cijevni propusti. Ako su nepravilno projektirani ili instalirani, ti prijelazi mogu 
imati ozbiljnu eroziju (Harris i dr. 2008). Najčešća rješenja takvih situacija na terenu izvode se pomoću postavljanja betonskih cijevnih propusta za manje vodotoke, dok se za veće vodotoke grade različite mosne konstrukcije. Funkcija je propusta odvođenje vode kroz trup ceste iz odvodnih kanala i stalnih ili povremenih vodotoka. Međutim, ako su oni zatrpani, gubi se prvobitna funkcija te se prelijeva i otječe voda po kolniku, što dovodi do razaranja kolničke konstrukcije (Sokolović i Bajrić, 2015). Woods i dr. (2007) otkrili su da je velika većina sedimenta u šumske potoke na području zapadne Montane dolazila iz samo nekoliko propusta na cestama.

Samu odluku o odabiru tipa vodopropusnoga objekta donosi projektant prilikom terenskih radova na trasiranju prometnice. Propusti su osjetljivi na začepljenje ako se s nagnutih padina ne uspije spriječiti taloženje tla ili drugih ostataka u kanalima, ili ako nisu projektirani s dovoljnim nagibom da se izbjegne taloženje organskih ostatka, poput lišća i drvenastoga materijala (Edwards i dr. 2016). Minimalni promjer cijevnoga propusta je 15 inča $(38,1 \mathrm{~cm})$. Dimenzija cijevnoga propusta od 15 inča $(38,1 \mathrm{~cm})$ minimalna je preporučena veličina promjera za poprečnu odvodnju. Manji propusti mogu se začepiti otpadom i zahtijevaju često održavanje (BMP 2019).

Nažalost, rijetki su slučajevi da se koriste neki od poznatih obrazaca za izračun maksimalne količine vode $\left(Q_{\max }\right)$ koja teče, pa u takvim slučajevima vodopropusni objekt ne može propustiti najveću količinu vode koja se može pojaviti. Proračun maksimalne količine vode koja se javlja na šumskim cestama treba biti glavni ulazni podatak za dimenzioniranje propusnih objekata (odvodni kanali, rigoli, propusti). U literaturi postoji velik broj formula za proračun maksimalnoga protoka, a među njima je najčešće primjenjivana racionalna metoda koja zahtijeva precizne podatke o intenzitetu kiše i koeficijentu otjecanja (Letić $\mathrm{i}$ dr. 2004). Osim toga često se radi uštede početnih ulaganja, umjesto odgovarajuće mosne konstrukcije, kao rješenje uzima postavljanje paralelnih betonskih cijevni ili drugih improviziranih tipova propusta. Takva su rješenja najčešće s pogleda protoka velikih voda zadovoljavajuća, ali kod njih lako dolazi do začepljenja »zemljano-kamenim « nanosom ili ostatkom šumskih drvnih sortimenata nakon završetka radova na pridobivanju drva. Kao posljedica toga, a zbog lošega redovitoga održavanja tih objekata, učestala su značajna oštećenja i pojave izlijevanja vode na trasu prometnice i njezino erodiranje, što u krajnjem smislu uzrokuje povećane troškove održavanja.

Prema Pičmanu (2007) objekti za odvodnju na šumskim cestama dijele se na:
$\Rightarrow$ objekte za površinsku odvodnju (bočni ili postrani jarci, rigoli, odvodnja pomoću ivičnjaka, površinski propusti, procjednice i preljevnice)

$\Rightarrow$ objekti za podzemnu odvodnju (cijevni propusti, pločasti propusti, nadsvođeni propusti, plitke drenaže, duboke podzemne ili zatvorene drenaže).

Kada je riječ o mostovima kao tipu vodopropusnoga objekta, prema Kovačeviću i dr. (2007), kod malih raspona (4-6 m) kvalitetno su rješenje mostovi tipa armiranobetonske pločaste konstrukcije, koji uz odgovarajuća rješenja mosnih glava i krila, koja cijeloj konstrukciji daju monolitan izgled i kompaktnost, predstavljaju optimalna rješenja kod velikih i bujičnih voda. Kod većih raspona isti autori preporučuju spregnute mosne konstrukcije (čelik - beton).

Sokolović i Bajrić (2013b) navode da su na postojećim šumskim cestama u FBiH uglavnom zastupljeni drveni mostovi ograničena vijeka trajanja, čije trenutačno stanje traži ozbiljnu rekonstrukciju. Drvenih mostova na šumskim cestama u $\mathrm{FBiH}$ ima oko 1000 (Sokolović i Bajrić 2011).

Funkcionalnost vodopropusnih objekata na šumskim cestama iznimno je važna. Naime, zbog značajnijih oštećenja ili nemogućnosti propuštanja velikih voda razaraju se kolničke konstrukcije pa se zato odvijanje prometa u velikoj mjeri otežava ili kod težih oštećenja potpuno obustavlja. Papa i dr. (2015) navode razloge za rekonstrukciju šumskih cesta, a među pobrojanim ističu objekte površinske i podzemne odvodnje koji zahtijevaju značajne popravke, poboljšanja ili zamjenu te prijelaze preko vodotoka koji traže značajne popravke, poboljšanja ili zamjenu.

Izostanak redovitoga i periodičnoga održavanja šumskih cesta, posebno objekata za odvodnju površinskih i podzemnih voda uzrokuju značajna oštećenja te jačanje erozije na kolničkoj konstrukciji, što uvelike utječe na zamućenje vodotoka i izvorišta vode (Bajrić i dr. 2017). Uz to ubrzanju propadanja postojećih šumskih cesta prilično pridonose i suvremeni kamionski sustavi čije osovinsko opterećenje značajno premašuje nosivost prije izgrađenih šumskih cesta. Ceste izgrađene s minimalnim standardima ili ispod standarda mogu ubrzano erodirati pa se sedimenti zato nanose $\mathrm{u}$ vodne tokove (Grace III i Clinton 2007). Erozija je česta pojava na svim neasfaltiranim cestama, posebno za vrijeme jakih kišnih dana i na cestama strmih nagiba (Wang i dr. 2021). Izostanak vodopropusnih objekata ili loša rješenja odvodnje mogu izazvati niz negativnih posljedica na kolničkoj konstrukciji, što se posebno odnosi na intenziviranje erozijskih procesa. Otjecanje oborinske vode sa šumskih cesta također može po- 
većati veličinu i učestalost velikih voda $u$ potocima te pojačati eroziju, što negativno utječe na sposobnost transporta materijala (Orndorff 2017).

Kvalitetna rješenja vodopropusnih objekata imaju veliko značenje zbog propusne moći te omogućavanja nesmetanoga transporta sadržaja vodotoka ispod trupa ceste. Prema Elliotu i dr. (2009) voda koncentrirana u jarcima i kanalima veći je rizik od erozije iz sliva i može lakše odvojiti i transportirati talog. Vjerojatnije je da će jarci erodirati ako imaju ogoljelo tlo zbog nedavne gradnje ili održavanja.

Intenziviranje erozije na šumskim cestama nastaje najčešće zbog strmih nagiba, oštrih zavoja, strmih bočnih kosina, mekoga ili erozijskoga površinskoga materijala, nepravilnoga prijelaza preko potoka, blizine potoka i loše odvodnje (Lakel 2008).

\section{Područje istraživanja - Research area}

Podaci za potrebe ovoga rada prikupljeni su u gospodarskoj jedinici »Neretvica«, koja pripada Šumskogospodarskomu području (ŠGP) »Konjičko«. Cijeli ŠGP ima izražena orografska obilježja terena, često vrlo strme padine bogatih gustom mrežom planinskih vodotoka. Krajnja sjeverna točka istraživanoga područja nalazi se na koordinatama $\varphi=43^{\circ}$ $53^{\prime} 42^{\prime \prime}, \lambda=17^{\circ} 49^{\prime} 58^{\prime \prime}$, a najjužnija točka na koordinatama $\varphi=43^{\circ} 47^{\prime} 22^{\prime \prime}, \lambda=17^{\circ} 54^{\prime} 09^{\prime \prime}$.

Površina je GJ »Neretvica« 3597,46 ha. Najveći se dio šuma u tom području nalazi na nadmorskoj visini većoj od $800 \mathrm{~m}$. To je pojas bukovo-jelovih šuma koji na nadmorskoj visini od preko $1500 \mathrm{~m}$ prelazi u pojas subalpinske bukove šume (Šumskogospodarska osnova za ŠGD »Konjičko«, 2005).

U hidrografskom pogledu GJ »Neretvica« jako je bogata vodotocima. Ukupna je duljina hidrografske mreže $82,95 \mathrm{~km}$. Gustoća hidrografske mreže $\left(\mathrm{D}_{\mathrm{u}}\right)$ prema istraživanjima koja je provela Ljevo (2016) iznosi $2,31 \mathrm{~km} / \mathrm{km}^{2}$, a to prema Gavrilovićevoj (1972) kategorizaciji pripada vrlo jako razvijenoj hidrografskoj mreži $\left(D_{u}>2.0 \mathrm{~km} / \mathrm{km}^{2}\right)$.

Glavni je vodotok rijeka Neretvica koja teče sredinom gospodarske jedinice. Tu su još i manje rječice i potoci: Mala Neretvica, Duboki potok, Obaščica, Korita, Rudinski potok, Palinski potok, Račeva voda, Crni potok itd.

Osim guste hidrografske mreže GJ »Neretvica« odlikuje se i dobro razvijenom mrežom šumskih kamionskih cesta ukupne duljiine $98,7 \mathrm{~km}$, odnosno 30,12 m/ha (Ljevo 2016), što je čini jednom od najbolje otvorenih na području FBiH. Istraživano je područje prikazano na slici 1 .

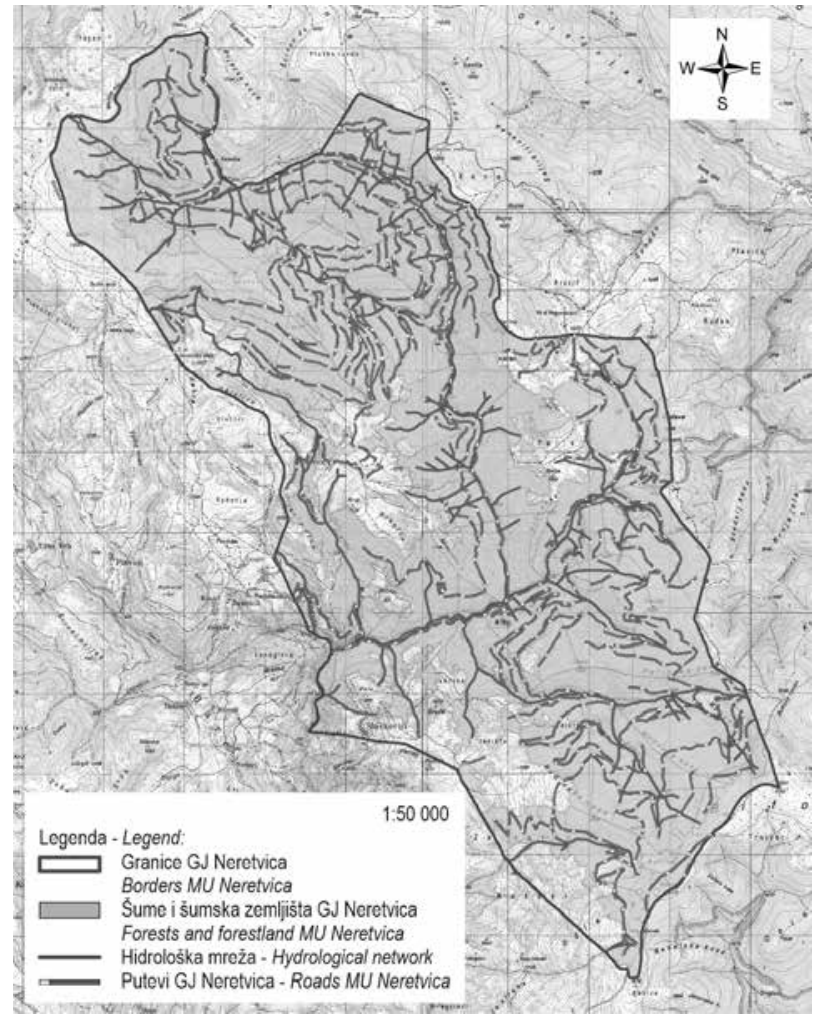

Slika 1. Područje istraživanja - GJ »Neretvica«

Fig. 1 Research area - MU »Neretvica»

\section{Metode rada-Methods of work}

Analiza je provedena kombinirano terenskim snimanjem poprečnih objekata za odvodnju površinskih i oborinskih voda te pomoću GIS-a. Na pozicijama presijecanja šumske ceste i vodotoka procijenjen je utjecaj. Prilikom procjene stupnja oštećenja otkriva se utjecaj vodnoga toka na šumske ceste pomoću ove bodovne ljestvice:

1. nema oštećenja (nema vidljivih tragova oštećenja na objektu)

2. malo oštećenje (stupanj je oštećenja nizak i nema utjecaja na odvijanje prometa)

3. značajno oštećenje (oštećenje je jasno vidljivo, sigurnost prometa ugrožena)

4. teško oštećenje (značajno oštećenje objekta koje onemogućuje odvijanje prometa).

Osim stupnja oštećenja procjenjuje se i funkcionalnost objekata za odvodnju pomoću ove ljestvice za mostove i propuste:

1. funkcionalnost mosta (propusta) normalna (voda slobodno istječe i nema nanesenoga materijala u profilu objekta) 
2. oslabljena funkcionalnost mosta (propusta), (prisutna određena količina nanesenoga materijala koja otežava nesmetan protok vode) i

3. onemogućena funkcionalnost mosta (propusta), (zbog oštećenja ili zatrpanosti nanesenim materijalom onemogućen protok vode).

Uz to je prilikom terenskih snimanja evidentirano i površinsko stanje kolničke konstrukcije u neposrednoj blizini vodopropusnoga objekta prema ovim kriterijima:

1. na kolničkoj konstrukciji nema vidljivih tragova oštećenja

2. na kolničkoj konstrukciji postoje tragovi oštećenja uzrokovani vodom, ali je promet moguć

3. na kolničkoj konstrukciji postoje značajnija oštećenja uzrokovana površinskim tokom koji ugrožavaju promet

4. na kolničkoj konstrukciji postoje teška oštećenja uzrokovana površinskim tokom koja u potpunosti onemogućuju promet.

$\mathrm{Na}$ osnovi procjene stupnja oštećenja i funkcionalnosti vodopropusnih objekata ocijenit će se utjecaj na erodiranje kolničke konstrukcije šumskih cesta.

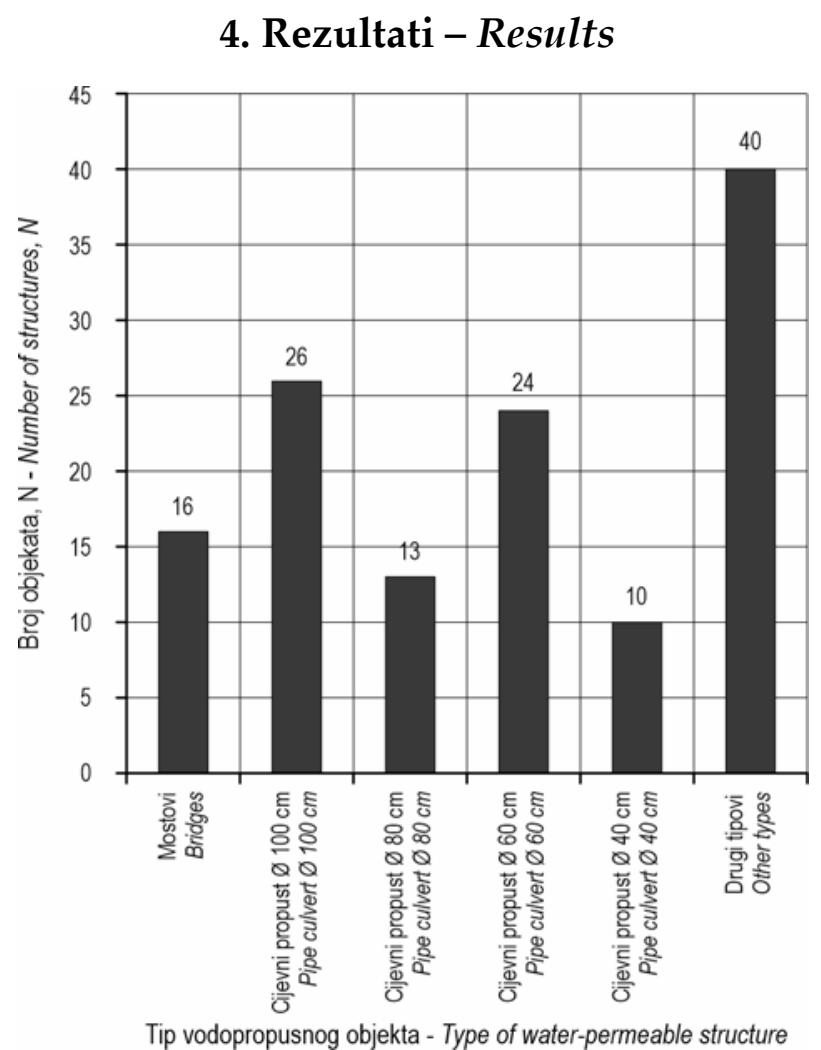

Slika 2. Ukupan broj vodopropusnih objekata po vrstama objekata Fig. 2 Total number of water-permeable structures by types of structures
Terenskim je snimanjem odabranoga lokaliteta evidentirano ukupno 129 vodopropusnih objekata različitih tipova, koji su prikazani na slici 2.

Kao što je vidljivo u grafičkom prikazu, osim standardnih vodopropusnih objekata (mostovi i betonski cijevni propusti) koji se najčešće susreću na šumskim cestama u $\mathrm{BiH}$, evidentirani su tzv. drugi tipovi vodopropusnih objekata. $U$ tu su kategoriju svrstani svi drugi tipovi propusta koji se nisu mogli definirati kao mostovi ili cijevni propusti. U svim je slučajevima bila riječ o improviziranim propustima ugrađenima u trup ceste koji su izgrađeni od kamenih ploča, a njih je bilo ukupno 40 .

Na svim evidentiranim vodopropusnim objektima procijenjena je težina oštećenja s obzirom na mogućnosti prometa, što je prikazano na slici 3. Analizom dijagrama može se zaključiti da nema teških oštećenja vodopropusnih objekata koji onemogućuju odvijanje prometa dok postoje mala i značajna oštećenja. Iz grafičkoga prikaza također je vidljivo da je oštećenja više kod manjih dimenzija propusta, a posebno kod tzv. drugih tipova (50\% tih objekata ima malo ili značajno oštećenje).

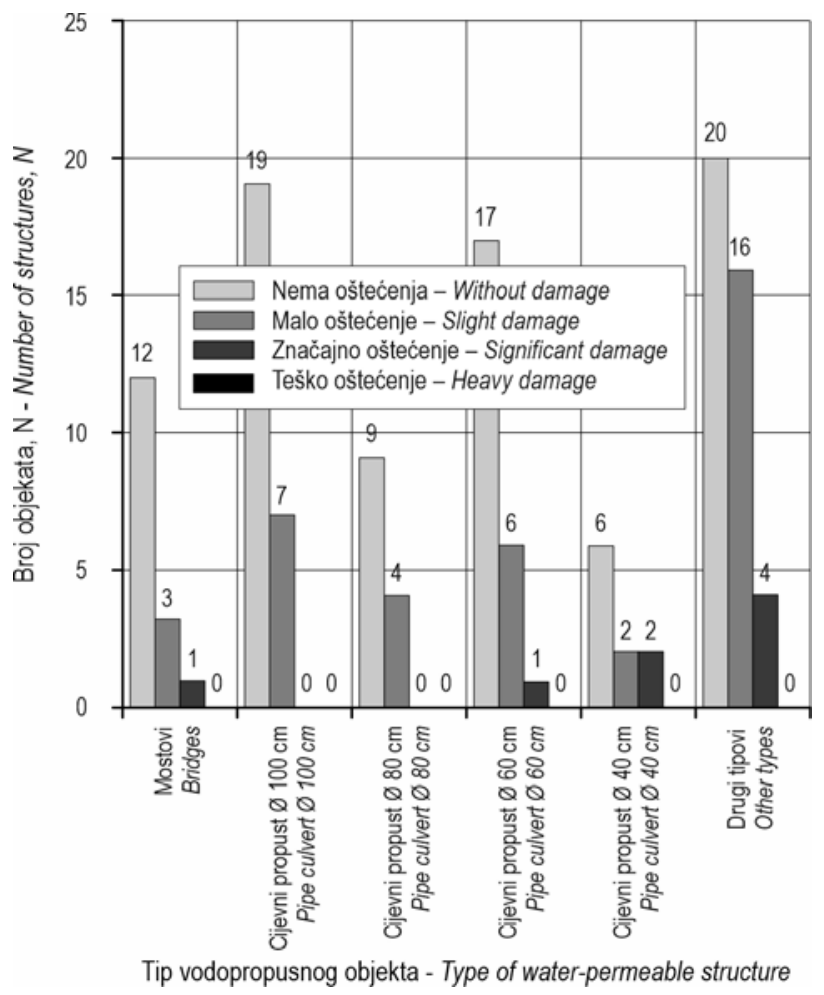

Slika 3. Pregled tipova vodopropusnih objekata po težini oštećenja

Fig 3. Overview of types of water-permeable structures by severity of damage 
Uz analizu stupnja oštećenja za sve je tipove vodopropusnih objekata ocijenjena i njihova funkcionalnost s obzirom na mogućnosti propuštanja vode. Analizom slike 4 uočava se da od ukupno 129 vodopropusnih objekata 93 ima dobru funkcionalnost, 32 oslabljenu funkcionalnost, dok je kod četiri vodopropusna objekta onemogućena funkcionalnost. Objekti koji su nefunkcionalni začepljeni su erodiranim materijalom pa voda teče preko kolničke konstrukcije. Objekti su također djelomično ili potpuno urušeni, što je dodatno ubrzalo začepljenje.

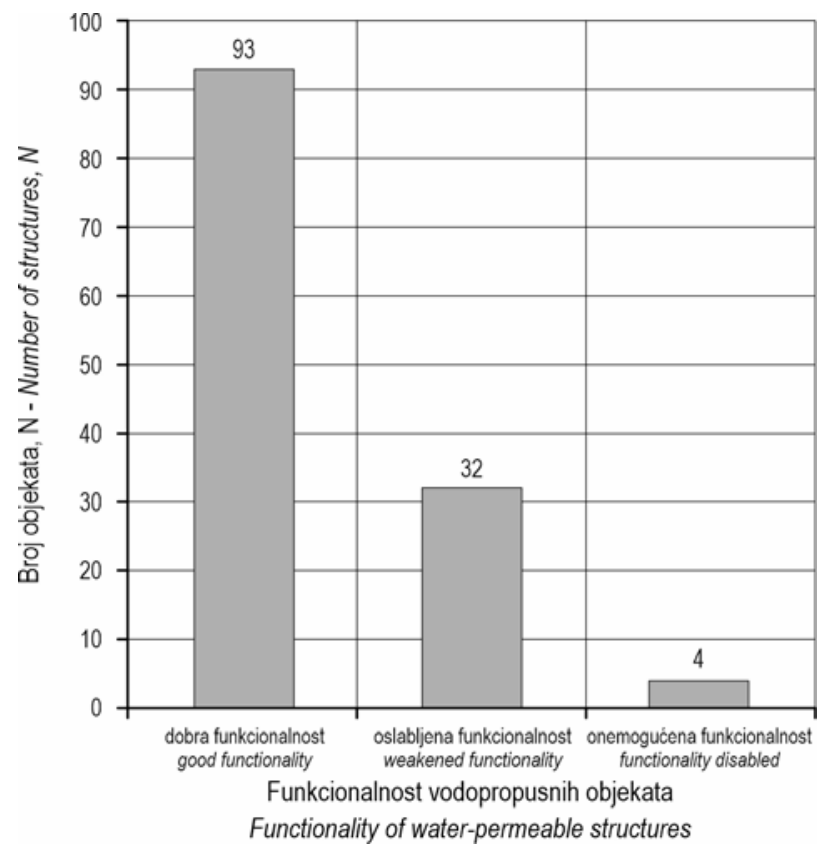

Slika 4. Pregled funkcionalnosti svih vodopropusnih objekata Fig. 4 Overview of functionality of all water-permeable structures

Kada se analizira funkcionalnost po tipovima propusta, i u ovom je slučaju uočljivo da je ona najlošija kod tzv. drugih objekata, što se jasno vidi na slici 5. Također je uočljivo da s malim oštećenjima ti objekti imaju oslabljenu funkcionalnost, dok je kod značajnih oštećenja njihova funkcionalnost onemogućena. Funkcionalnost svih objekata i prikaz funkcionalnosti po tipovima prikazani su slikama 4 i 5.

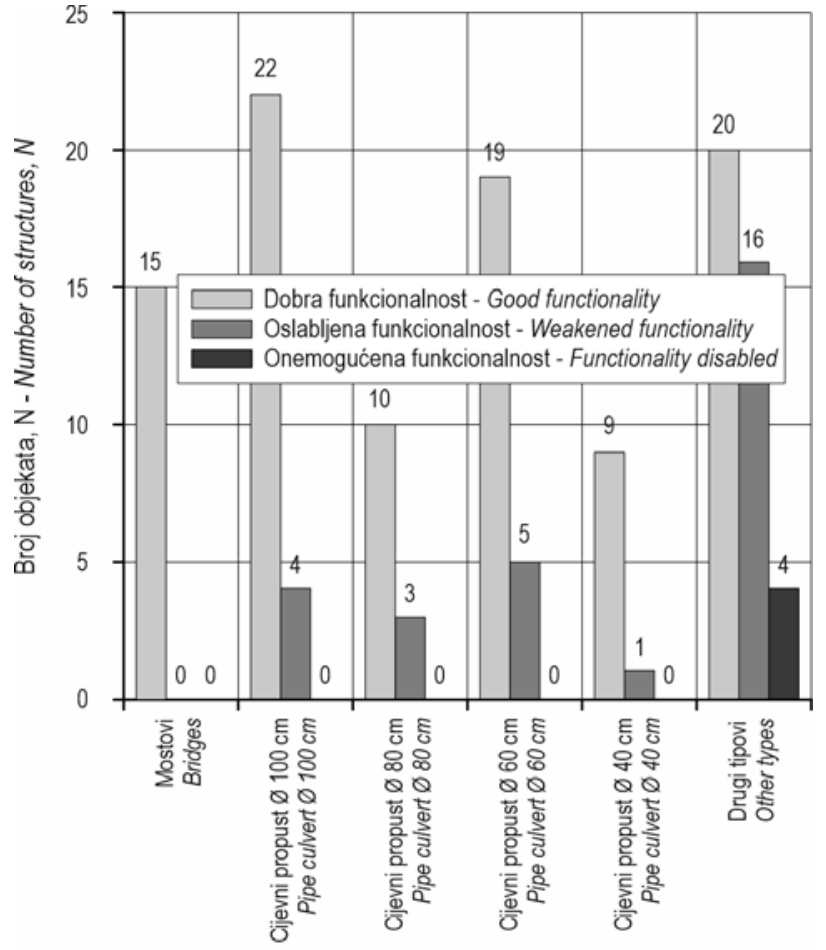

Tip vodopropusnog objekta - Type of water-permeable structure

Slika 5. Funkcionalnost vodopropusnih objekata unutar tipova objekata

Fig. 5 Functionality of water-permeable structures within structure types

Različita oštećenja objekata i njihove posljedice prikazane su na slikama 6-9.

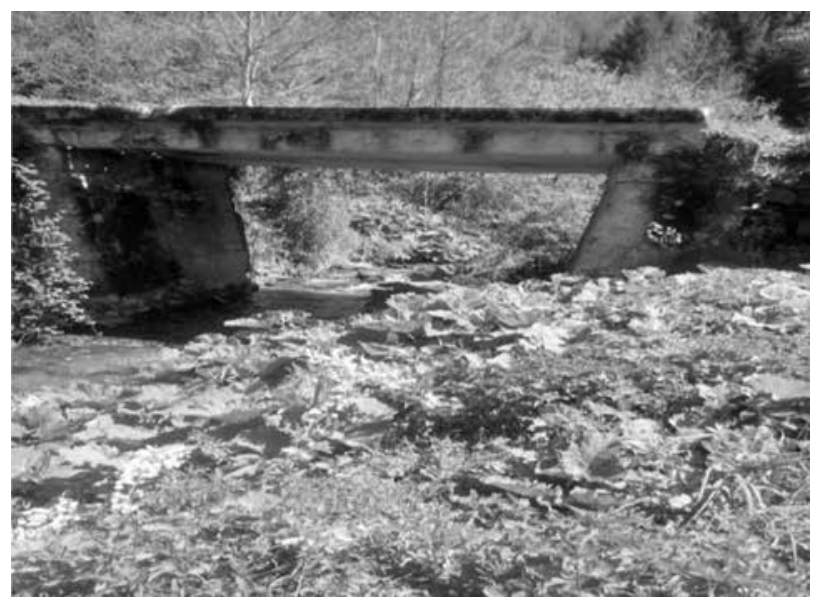

Slika 6. Oštećenje mosta na šumskoj cesti

Fig. 6 Damage to a forest road bridge 

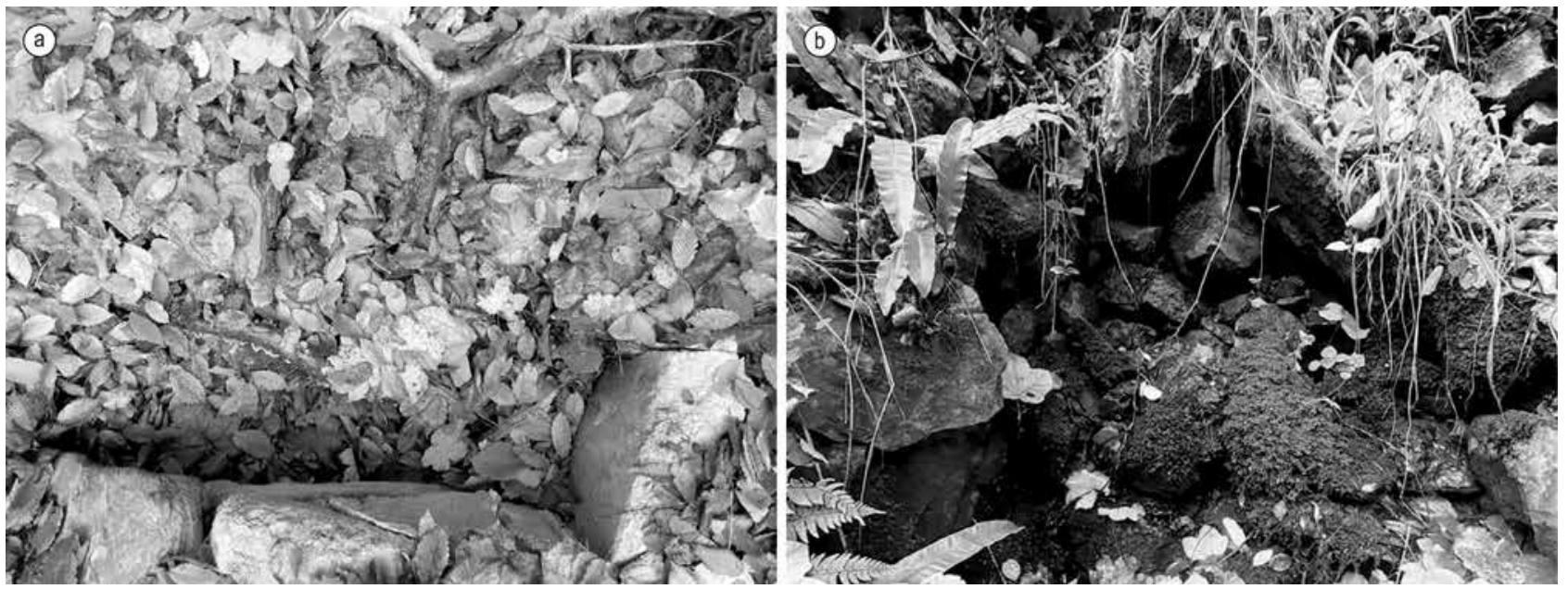

Slika 7a i 7b. Urušeni 'drugi tip' vodopropusnoga objekta

Fig. 7a and 7b Collapsed 'other type' of water-permeable structure
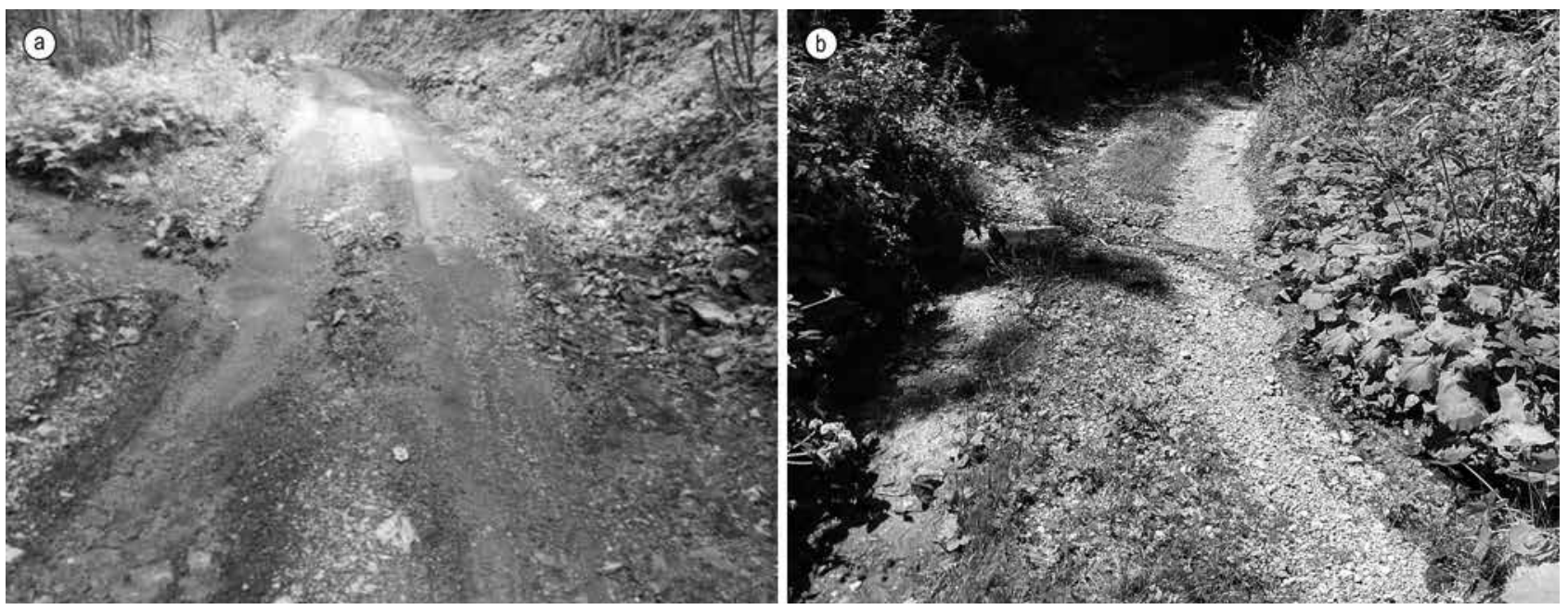

Slika 8a i 8b. Otjecanje vode preko kolnika

Fig. 8a and $8 b$ Water runoff over a roadway
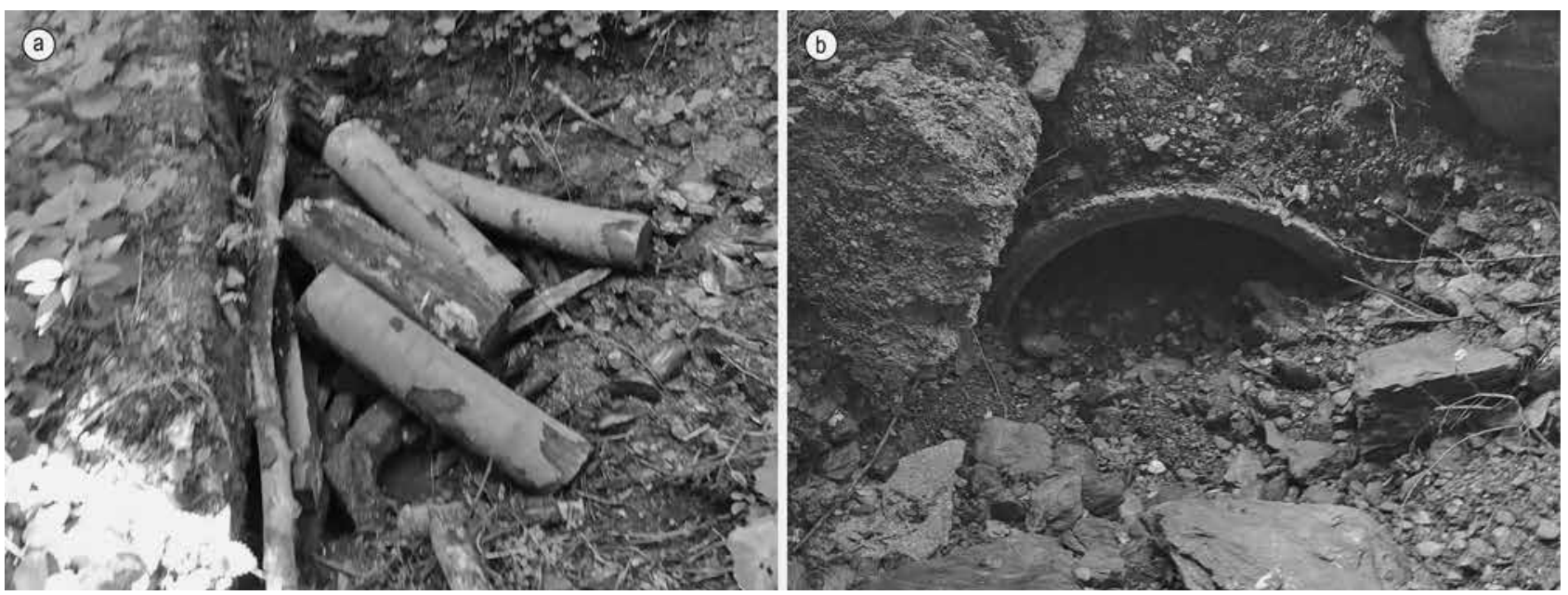

Slika 9a i 9b. Otežana funkcionalnost vodopropusnih objekata

Fig. 9a and 9b Aggravated functionality of water-permeable structures 
Utjecaj oštećenja i funkcionalnosti vodopropusnih objekata na erodiranje kolničke konstrukcije u neposrednoj blizini vodopropusnih objekata prikazan je na slici 10 .

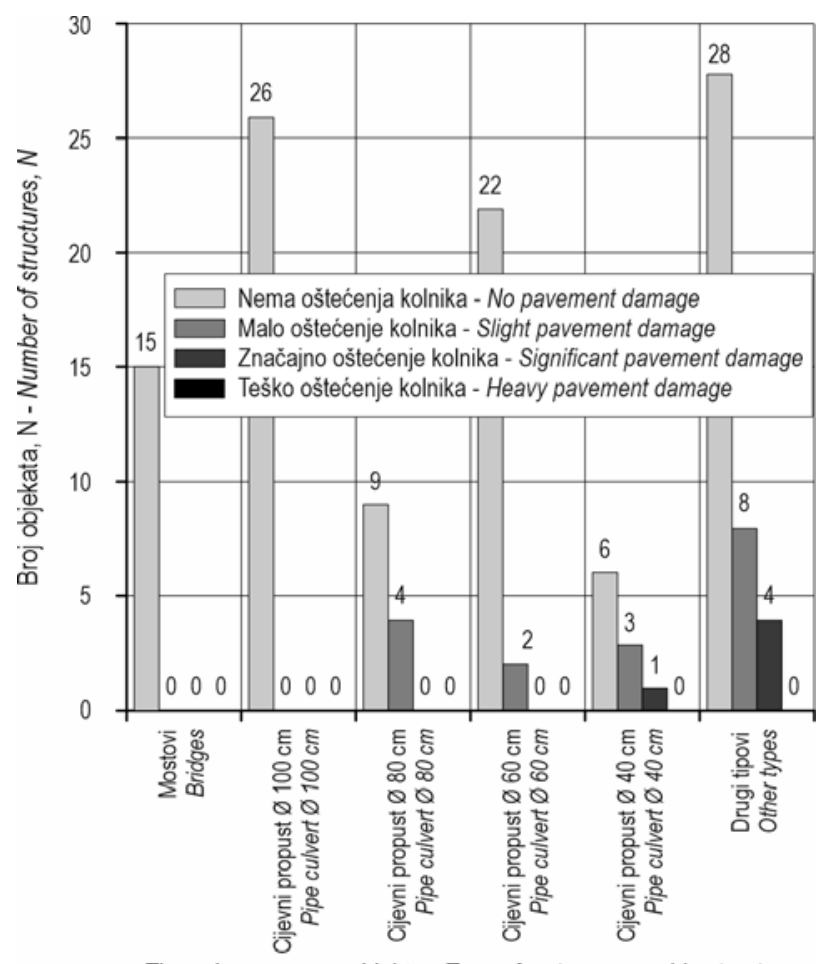

Tip vodopropusnog objekta - Type of water-permeable structure

Slika 10. Intenzitet oštećenja kolnika u neposrednoj blizini vodopropusnih objekata

Fig. 10 Intensity of road damage in immediate vicinity of water-permeable structures

\section{Rasprava i zaključci - Discussion and conclusions}

Gradnja šumskih cesta $\mathrm{u}$ brdsko-planinskim područjima na kojima postoji bogata hidrografska mreža nije moguća a da se pri tom često međusobno ne presijecaju prometnice i vodni tokovi. Mjesta presijecanja mogu biti vrlo osjetljiva ako na odgovarajući način nije odabran pravilan tip i dimenzije vodopropusnoga objekta. Šumski cestovni prijelazi glavni su izvor sedimenta u potocima i donose više taloga u potoke od bilo koje druge aktivnosti upravljanja zemljištem (Meehan 1991). Povezanost cesta i potoka povećava vjerojatnost otjecanja vode s cesta, a sediment koji se transportira stići će do potoka (Croke i dr. 2005). Također, sam izbor tehničkih elemenata šumskih cesta može imati utjecaj na brzinu površinskoga otjecanja i eroziju. $S$ povećanjem nagiba ceste povećava se brzina otjecanja i erozija
(Dalir i dr. 2014). Jedan od osnovnih problema koji imaju negativan utjecaj na erodiranje kolničke konstrukcije, ogleda se u lošem redovitom i periodičnom održavanju i uzdužnih jaraka za odvodnju i vodopropusnih objekata. U šumarskoj se struci vrlo često zanemaruje funkcionalnost uzdužnih (jarci) i poprečnih objekata (propusti i mostovi), pri čemu se prilikom saniranja u najvećem broju slučajeva sanira samo kolnička konstrukcija kako bi se osigurao siguran promet kamionima za prijevoz šumskih drvnih sortimenata. Praksa kontrole otjecanja, poput rekonstrukcije šumskih cesta nakon izgradnje, bitna je za smanjenje količine otjecanja i smanjenje taloga (Gholami i dr. 2009).

Istraživanje na području GJ »Neretvica« pokazuje da se kod pravilnoga izbora tipa vodopropusnoga objekta te njegovih dimenzija omogućuje nesmetan prirodni protok površinske i oborinske vode. Kod protoka u slučajevima gdje su kao vodopropusni objekti izgrađeni mostovi, nema negativnoga utjecaja, odnosno omogućen je slobodan protok vode bez zadržavanja nanosa. Također, u slučajevima kada su kao vodopropusni objekti izgrađeni kao betonski propusti promjera 40,60, 80 i $100 \mathrm{~cm}$, od ukupno 73 objekta u $13(17,8 \%)$ slučajeva postoji oslabljena funkcionalnost, odnosno djelomično zadržavanje nanosa materijala. U slučajevima kada su se pri izgradnji šumskih cesta koristili drugi tipovi objekata, koji su improvizirano građeni od kamenih ploča djelomično obrađenih na terenu, od ukupno 40 takvih objekata 16 (40\%) ima otežanu funkciju odvodnje, dok je kod 4 (10 \%) slučaja odvodnja u potpunosti onemogućena i voda otječe kolničkom konstrukcijom. Također, oštećenje kolničke konstrukcije $\mathrm{u}$ smislu vidljivoga erodiranja $\mathrm{u}$ neposrednoj blizini vodopropusnih objekata kod mostova i betonskih cijevi promjera 60, 80 i $100 \mathrm{~cm}$ nisu evidentirani erozijski procesi na kolničkoj konstrukciji uzrokovani površinskim otjecanjem. Za razliku od toga, u slučaju propusta promjera $40 \mathrm{~cm}$ i kod drugih tipova vodopropusnih objekata evidentirano je erodiranje kolničke konstrukcije, pri čemu je u četiri slučaja kod drugih tipova ta pojava izražena.

Dobiveni rezultati istraživanja jasno pokazuju da se pravilnim izborom vodopropusnoga objekta, u prvom redu odgovarajućega promjera, uz provođenje mjera redovitoga i periodičnoga održavanja, smanjuje opasnost od negativnoga utjecaja na erodiranje kolničke konstrukcije.

Erozija cesta smanjuje njihov vijek trajanja, povećava troškove njihova održavanja, oštećuje vozila i nanosi štetu vodenim tokovima u okruženju (Riedel i dr. 2007). 


\section{Literatura - References}

Bajrić, M., A. Lojo, J. Musić, F. Skopljak, S. Omerović, S., Karšić, 2017: Elaborat o gospodarenju šumama u zonama sanitarne zaštite izvorišta vode Kruščica, općina Vitez. Vlada Srednjobosanskog kantona, Ministarstvo poljoprivrede, vodoprivrede i šumarstva, Travnik, 143 str.

Best Management Practices for Water Quality - Field Guide, 2019: Virginia Department of Forestry, str. 98.

Croke, J., S. Mockler, P. Fogarty, I. Takken, 2005: Sediment concentration changes in runoff pathways from a forest road network and the resultant spatial pattern of catchment connectivity. Geomorphology, 68(3-4): 257-268. https://doi.org/10.1016/j.geomorph.2004.11.020

Dalir, P., R. Naghdi, V. Gholami, 2014: Modelling of forest road sediment in the northern forest of Iran (Lomir Watershed). Journal of Forest Science, 60(3): 109-114. https:// doi.org/10.17221/91/2013-JFS

Edwards, P. J., F. Wood, R. L. Quinlivan, 2016: Effectiveness of Best Management Practices that Have Application to Forest Roads. A Literature Synthesis, Forest Service Northen Research Station, General Tehnical Report NRS, p. 163.

Elliot, W. J., R. B. Foltz, P. R. Robichaud, 2009: Recent findings related to measuring and modeling forest road erosion. 18th World IMACS/MODSIM Congress, Cairnas, Australia 13-17 July 2009, pp. 4078-4084.

Gavrilović, S., 1972: Inžinjering o bujičnim tokovima i eroziji. »Izgradnja«, Beograd, 292 str.

Gholami V., E. Jokar, M. Azodi, H. A. Zabardast, M. Bashirgonbad, 2009: The influence of anthropogenic activities on intensifying runoff generation and flood hazard in Kasilian watershed. Journal of Applied Sciences, 9: 37233730. https://doi.org/10.3923/jas.2009.3723.3730

Grace III, J. M., B. D. Clinton, 2007: Protecting soil and water in forest road management. American Society of Agricultural and Biological Engineers, vol. 50(5): 1579-1584.

Harris, R., J. Gerstein, P. Cafferata, 2008: Changes in Stream Channel Morphology Caused Harvesting Plans in Northwestern California. Western Journal of Applied Forestry, 23(2):69-77. https://doi.org/10.1093/ wjaf/23.2.69

Ice, G. G., D. G. Neary, P. W. Adams, 2004: Effects of wildfire on soils and watershed processes. Journal of Forestry, 102(6): 16-20.

JP »Bosanskohercegovačke šume«, 2005: Šumskogospodarska osnova za ŠPP »Konjičko« (2005-2014). Sarajevo, 379 str.

Kovačević, B., M. Bajrić, Dž. Sokolović, 2007: Izbor rasponske konstrukcije i njen uticaj na regulaciju bujičnog toka. Radovi Šumarskog fakulteta Univerziteta u Sarajevu, 1: 81-90.
Lakel III, W. A., 2008: Effects of Forestry Streamside Management Zones on Stream Water Quality, Channel Geometry, Soil Erosionm and Timber Management in the Virginia Piedmont. Dissertation, Virginia Polytechnic Institute and State University, $134 \mathrm{p}$.

Letić, Lj., R. Ristić, I. Malušević, 2004: Proračun merodavne količine vode za evakuacione objekte šumskih puteva. Udruženje šumarskih inženjera i tehničara Srbije, Šumarstvo, 4: 87-96.

Ljevo, E., 2016: Uticaj hidrografske mreže na primarnu infrastrukturu u G.J. »Neretvica«. Diplomski rad, Šumarski fakultet Univerziteta u Sarajevu, 70 str.

Meehan, W. R., 1991: Influences of forest and rangeland management on salmonid fishes and their habitats. Special Publication 19. Bethesda, MD: American Fisheries Society, p. 622.

Orndorff, A., 2017: Evaluating the Effects of Sedimentation from Forest Roads: A Review. Soil and Water Science Department, University of Florida, p. 38.

Papa, I., T. Pentek, H. Nevečeler, K. Lepoglavec, A. Đuka, B. Šafran, S. Risović, 2015: Raščlamba tehničkih značajki sustava odvodnje postojećih šumskih cesta radi utvrđivanja potrebe njihove rekonstrukcije - studija slučaja za G.J. »Belevine« NPŠO Zalesina. Šumarski list, 139(11-12): 497-519.

Pičman, D., 2007: Šumske prometnice. Udžbenik, Šumarski fakultet Sveučilišta u Zagrebu, 460 str.

Riedel, M. S., L. W. Swift Jr. J. M. V. Barton, D. Clinton, 2007: Forest road erosion research at the Coweeta Hydrologic Laboratory. Advancing the fundamental sciences. Proceedings of the Forest Service National earth sciences conference, San Diego, U.S. Department of Agriculture, Forest Service, Pacific Northwest Research Station. pp. 197-205.

Sokolović, Dž., 2018: Šumska transportna infrastruktura. Šumarski fakultet Univerziteta u Sarajevu, 209 str.

Sokolović, Dž., M. Bajrić, 2011: Šumska transportna infrastruktura u FBiH. Studija, Federalno Ministarstvo poljoprivrede, vodopriv rede i šumarstva, Sarajevo, 75 str.

Sokolović, Dž., M. Bajrić, 2013a: Otvaranje šuma. Univerzitetski udžbenik, Šumarski fakultet Univerziteta u Sarajevu, 250 str.

Sokolović, Dž., M. Bajrić, 2013b: Šumska prometna infrastruktura u Federaciji Bosne i Hercegovine. Nova mehanizacija šumarstva, 34: 39-50.

Sokolović, Dž., M. Bajrić, 2015: Analiza mogućeg uticaja šumske transportne infrasatrukture na razorno djelovanje brdsko planinskih vodotoka. Posebna izdanja, knjiga CLXI, Simpozij - Upravljanje rizicima od poplava i ublažavanje njihovih štetnih posljedica, Akademija nauka i umjetnosti Bosne i Hercegovine - Odjeljenje prirodnih i matematskih nauka, Sarajevo, 111-121. 
Wang, C., B. Liu, Q. Yang, G. Pang, Y. Long, L. Wang, R. M. Cruse, W. Dang, X. Xin Liu, E. Wang, 2021: Unpaved road erosion after heavy storms in mountain areas of northern China. International Soil and Water Conservation Research, 1-9. https://doi.org/10.1016/j.iswcr.2021.04.012
Woods, S. W., B. Sugden, B., Parker, 2007: Sediment travel distances below drivable drain dips in western Montana. University of Montana, College of Forestry and Conservation. The 29th Council on Forest En gineering Conference. Coeur d'Alene, Idaho, July 30-August 2, 2006. W. Chung and H. S. Han, editors, pp. 251-263.

\section{Abstract}

\section{Significance of Functionality of Water-Permeable Structures in Erosion Protection of Forest Roads}

Water permeable structures on strip roads play a very important role in regulating the flow of surface water and rainwater. Although the forestry operative of BEH does not use patterns that can be used to correctly determine the dimensions of water-permeable structures, most often the selection of the dimensions of the structure that can ensure the smooth flow of water is done experientially.

Previous analyses show that investments in forest road infrastructure are insufficient (Sokolović and Bajrić 2011, 2013) and that this is the most common reason for the poor condition of forest road infrastructure. Erosion is a common occurrence on all unpaved roads, especially in heavy rain events and on steep slopes (Wang et al. 2021). Poor technical solutions, along with irregular maintenance of water-permeable structures, are a common cause of intensification of erosive processes and destruction of the road structure.

In the present study, a total of 129 water-permeable structures of various types were analyzed, of which 16 bridges, 73 concrete pipe culverts, and 40 'other' types (improvised solutions of water-permeable structures, most often made of stone slabs). Bridges have the most efficient functionality, which allows water to flow freely through the flow profile. Also, concrete culverts of larger dimensions $(\varnothing 80$ and $100 \mathrm{~cm}$ ) have better functionality than culverts of smaller dimensions $(\varnothing$ 40 and $60 \mathrm{~cm}$ ). Namely, in the case of specific small culverts, frequent partial blockages were observed, the maintenance of which was difficult due to the small dimensions of the culvert.

The worst functionality was observed with 'other types' of water-permeable structures, where collapses often occur, and as a result, they cannot be cleaned and have to be replaced instead. Of the total number of 'other types' of structures, 50\% have difficult or disabled functionality, with $20 \%$ of the total number having disabled functionality. It is obvious that the choice of the type of water-permeable structures, as well as their dimensions, play a very important role when it comes to their future functionality.

Also, field research has determined the direct correlation between the functionality of water-permeable structures and the occurrence of erosive processes on the pavement structure in the immediate vicinity. That is, in the case of structures with impaired or disabled functionality, the water partially or completely overflows over the pavement structure, whereby the surface rubs off the pavement and causes its erosion.

Keywords: forest roads, water permeable structures, pavement construction, water erosion 
Adrese autorâ - Authors' addresses:

Prof. dr. sc. Muhamed Bajrić ${ }^{*}$

e-pošta:m.bajric@sfsa.unsa.ba

Prof. dr. sc. Dževada Sokolović

e-pošta: dz.sokolovic@sfsa.unsa.ba

Šumarski fakultet Univerziteta u Sarajevu

Zagrebačka 20

71000 Sarajevo

BOSNA I HERCEGOVINA

Elma Ljevo

Šumarstvo »Prenj« d.d. Konjic

Sarajevska 1

88400 Konjic

BOSNA I HERCEGOVINA

Adnan Hodžić

ŠGD Hercegbosanske šume d.o.o. Kupres

Splitska bb

80320 Kupres

Primljeno (Received): 3. 9. 2021.

BOSNA I HERCEGOVINA

Prihvaćeno (Accepted): 14. 10. 2021.

* Glavni autor - Corresponding author 